\title{
EXPERIMENTAL STUDIES OF ENERGY SYSTEMS OF AUTOMATIC CONTROL HEAT SUPPLY OF RESIDENTIAL BUILDINGS AND METHODS OF INCREASING THEIR EFFICIENCY
}

\author{
V.L. Kodkin, kodkina2@mail.ru,
}

A.S. Anikin, anikinsasha@gmail.ru,

A.A.Baldenkov, baloo@mail.ru,

A.Y. Kachalin, kachalin89@inbox.ru

South Ural State University, Chelyabinsk, Russian Federation

\begin{abstract}
Results of trial operation of system of heat supply of the residential building with the optimized processes of regulation of temperature of the heat carrier are given in article. The actual indicators of volumes of the consumed gas for several months 2015 and values of temperature of external air are analyzed. It is shown that "factory" settings of controllers don't ensure effective functioning, especially at temperatures of external air close to $0{ }^{\circ} \mathrm{C}$. The data, which showed that the optimization of processes in heating systems developed techniques for increasing their efficiency by $10-15 \%$. On the basis of pilot studies in a suburban boiler room with considerable losses in a heating main, the method of increase in their energy efficiency by increase in giving of the heat carrier is offered. The method is realized by means of the converter of frequency installed for control of the network pump. The experiments have confirmed efficiency of the offer.
\end{abstract}

Keywords: optimization of heating system, energy efficiency of buildings, coolant flow.

\section{Introduction}

The researches of operating modes of the system of automatic control of heating of the residential building containing a boiler room with three coppers and thermal point with two contours of heat supply conducted in 2014-2015 have shown that at the parameters of regulators recommended by firms manufacturers of the equipment in system the processes possessing a number of shortcomings are formed (Fig. 1).

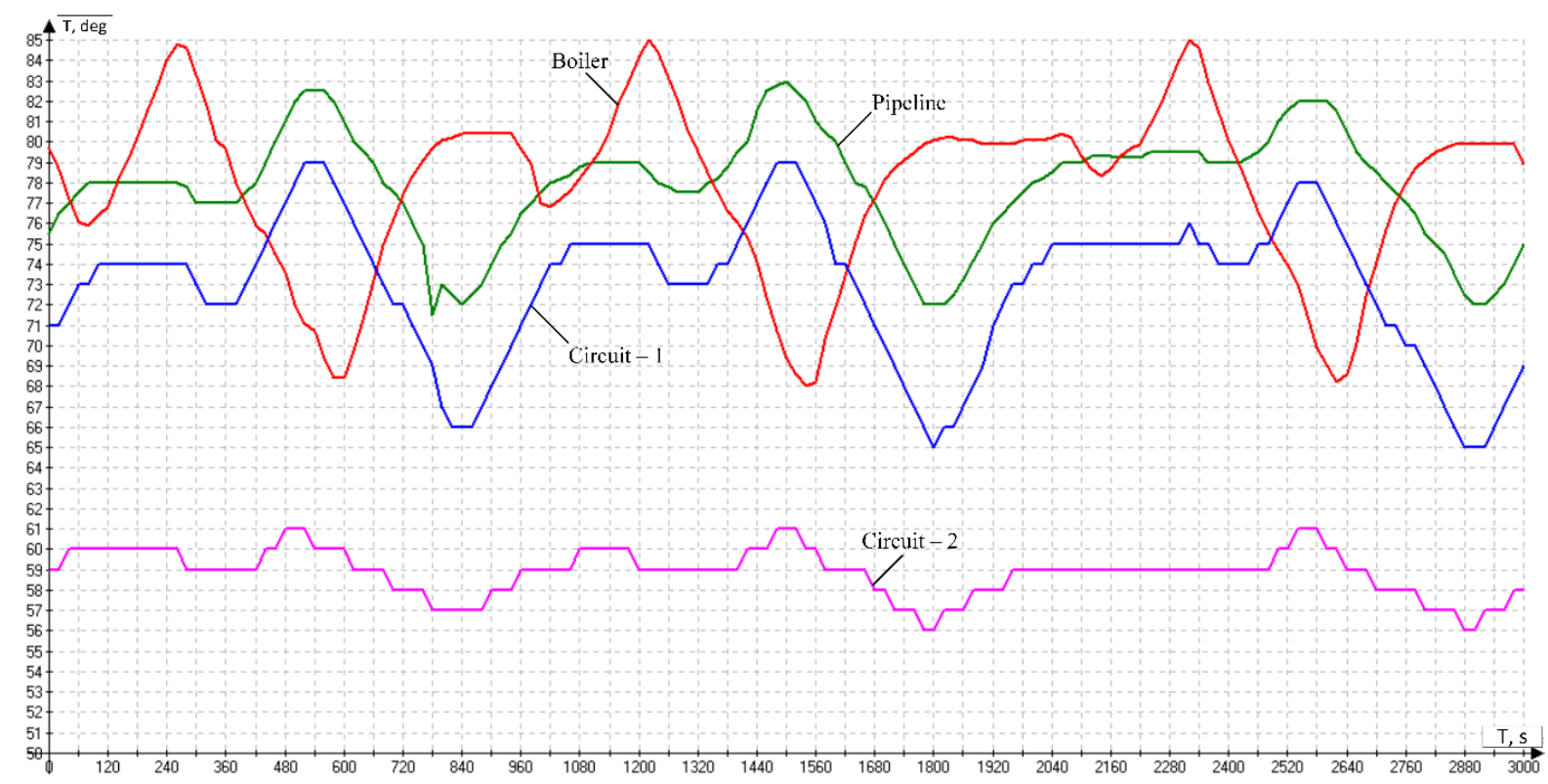

Fig. 1. Processes in system of heat supply at "factory" settings of regulators

1. The analysis of energy efficiency of system during trial operation

First of all, it is necessary to mark out the oscillatory nature of processes in coppers and contours of regulation with an amplitude to $8-10{ }^{\circ} \mathrm{C}$ and the period of 7-20 min. To exclude influence of these fluc- 
tuations on temperature in rooms and not to allow her decrease, temperature in contours was overestimated, and in a boiler room, as a rule, process reached maximum admissible values of temperature of the heat carrier [1]. At the same time, naturally, level of consumption of energy resources rather high, and therefore, system effectiveness very low.

The analysis of consumption of gas in this system for several months 2014-2015 is carried out. Charts of temperature of external air and the volume of the gas consumed per days are provided on the diagrams (Fig. 2) and in the Table 1. The analysis has shown, at $T_{a v} \approx 0{ }^{\circ} \mathrm{C}$ (March 2014, October 2015) and at $T_{a v} \approx-10^{\circ} \mathrm{C}$ (February 2015, November 2015) volumes of the consumed gas differ slightly $64,6 \cdot 10^{3} ; 50,3 \cdot 10^{3} ; 72,2 \cdot 10^{3} ; 76,1 \cdot 10^{3} \mathrm{~m}^{3}$ respectively. I.e. system effectiveness at low temperatures $\left(-10^{\circ}\right.$ below $)$ is significantly higher, than at ambient temperature close to $0{ }^{\circ} \mathrm{C}$. It testifies to bad indicators of system of regulation.
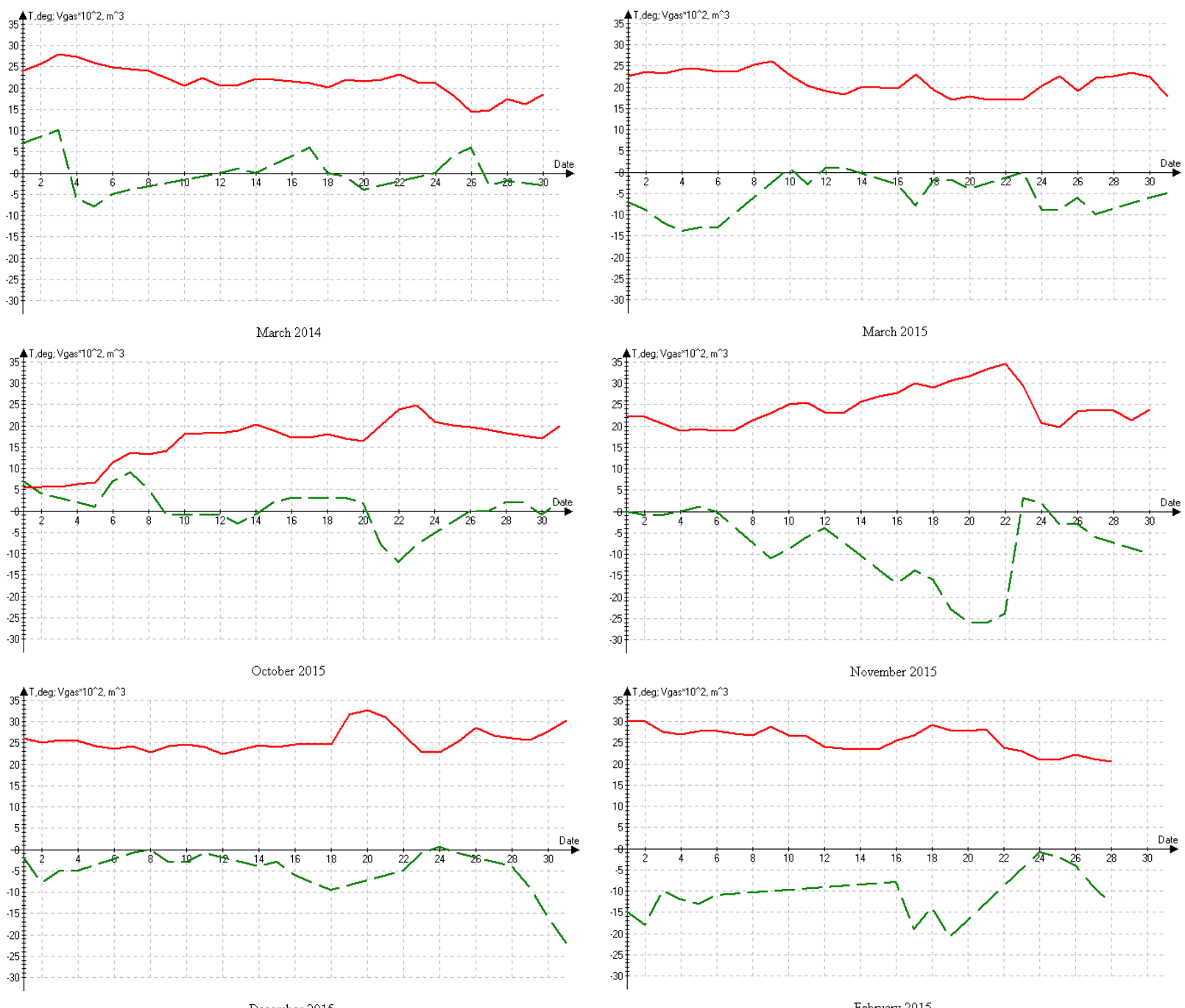

Fig. 2. The average daily temperature and the volume of gas consumed per day

Summary table consumption of gas and average daily temperature of external air on months

Table 1

\begin{tabular}{|l|c|c|c|c|c|c|}
\hline & $\begin{array}{c}\text { March } \\
2014\end{array}$ & $\begin{array}{c}\text { February } \\
2015\end{array}$ & $\begin{array}{c}\text { March } \\
2015\end{array}$ & $\begin{array}{c}\text { October } \\
2015\end{array}$ & $\begin{array}{c}\text { November } \\
2015\end{array}$ & $\begin{array}{c}\text { December } \\
2015\end{array}$ \\
\hline $\begin{array}{l}\text { Gas consumption } \\
\text { in a month, }{ }^{3}\end{array}$ & 64651,2 & 72249,6 & 63321,5 & 50307,7 & 76183,8 & 80100,4 \\
\hline $\begin{array}{l}\text { Average daily temperature } \\
\text { in a month, }{ }^{\circ} \mathrm{C}\end{array}$ & 0 & $-10,15$ & $-5,39$ & +2 & $-8,678$ & $-4,876$ \\
\hline
\end{tabular}




\section{Краткие сообщения}

Works on optimization of processes of regulation of temperature of the heat carrier [1], which have reduced amplitudes of fluctuations of temperature to $1-2{ }^{\circ} \mathrm{C}$ and have allowed increasing system effectiveness (Fig. 3) are carried out.

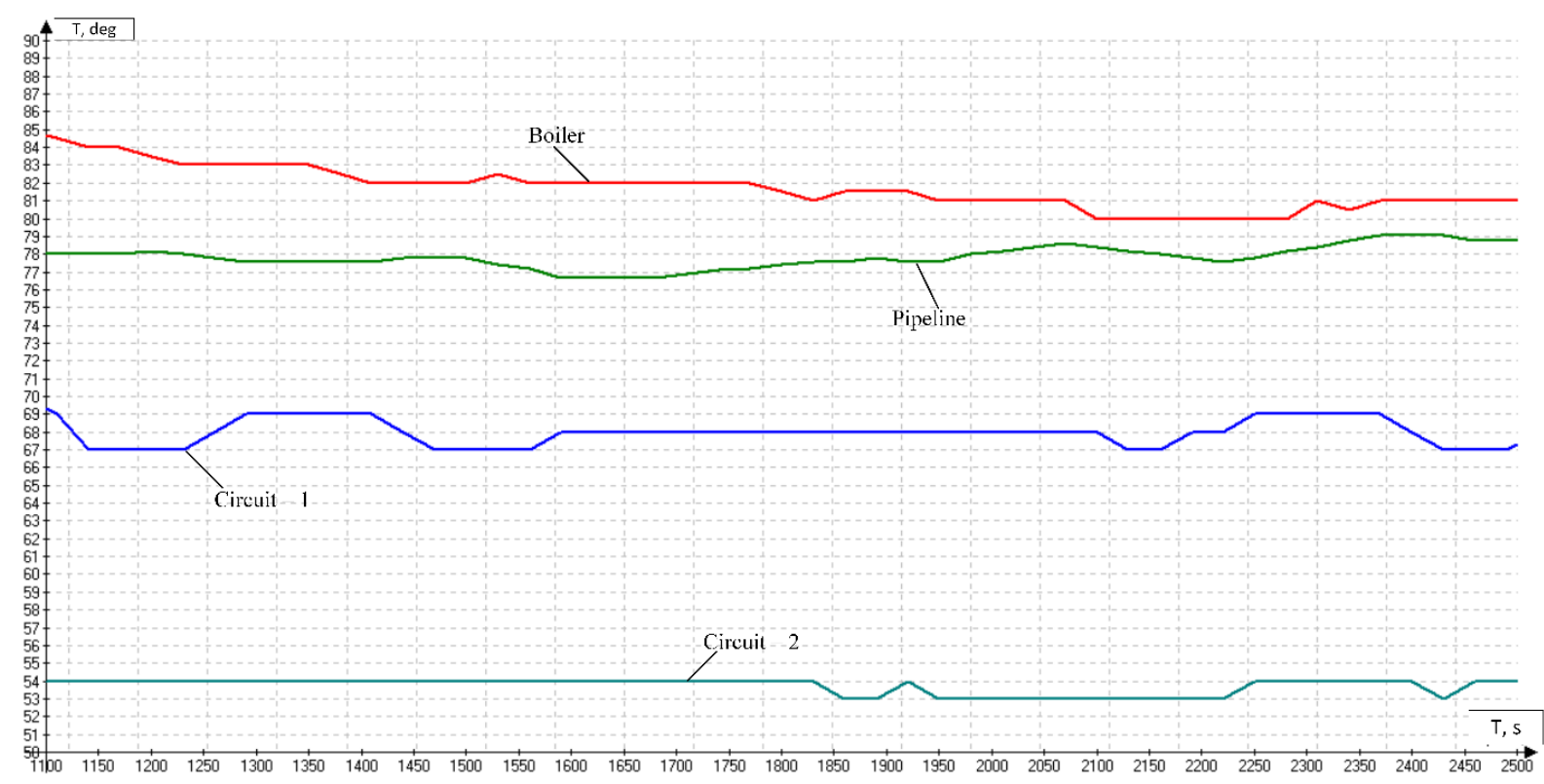

Fig. 3. Processes in the optimized system

So, from March 1 to March 15, 2015 average air temperature $-6{ }^{\circ} \mathrm{C}$ and consumption of 2,38 $10^{3} \mathrm{~m}^{3}$ per day, and after optimization of system of heat supply - from March 15 to March 31, $2015-5^{\circ} \mathrm{C}$, and $1,84 \cdot 10^{3} \mathrm{~m}^{3}$ per day, according to (Fig. 4, Table 2). At the same time, as shown in [1] there is an opportunity to reduce heat carrier temperature in contours and in a boiler room (Fig. 3).

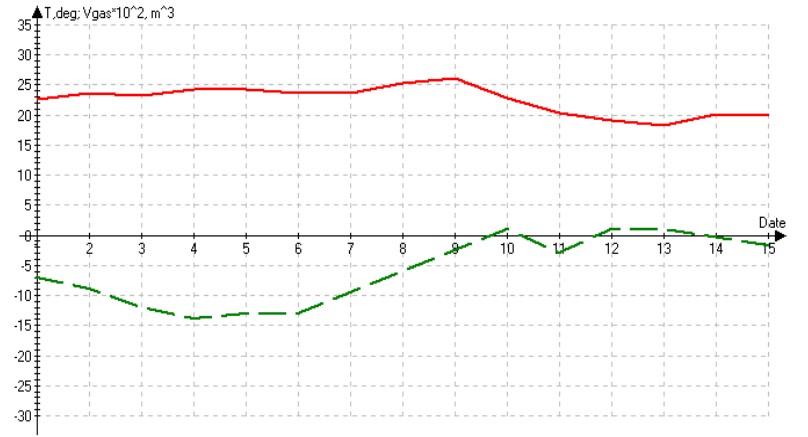

March $2015(1-15)$ before optimization

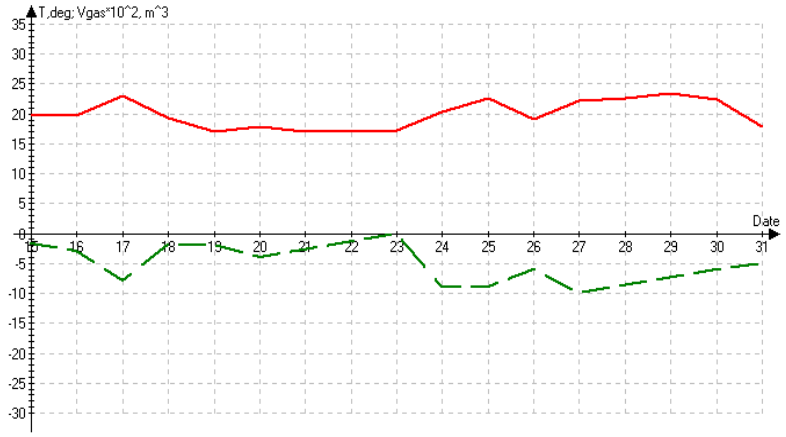

March 2015 (15 - 31) after optimization

Fig. 4. The average temperature of the outside air and the gas volume consumed per day before and after optimizing the system parameters

Consumption of gas and average daily temperature of external air in March 2015

Table 2 before and after optimum setup of the regulator

\begin{tabular}{|l|c|c|}
\hline & Consumption of gas, $\mathrm{m}^{3} /$ day & Average daily temperature, ${ }^{\circ} \mathrm{C}$ \\
\hline $\begin{array}{l}\text { On March 1 - on March 15 } \\
\text { (before change of settings) }\end{array}$ & 2380 & $-6,3$ \\
\hline $\begin{array}{l}\text { On March 16 - on March 31 } \\
\text { (after change of settings) }\end{array}$ & 1840 & $-4,9$ \\
\hline
\end{tabular}

Thus the analysis of trial operation of system of heat supply has shown that optimization of work of contours can give effect comparable with introduction of systems of the combined heating [2], and sys- 
tems of heat supply with control of air temperature in rooms [2] which, certainly, are effective, but are a little suitable for housing-and-municipal city systems of heat supply.

\section{Improving energy efficiency by increasing coolant flow}

In experimental studies in a suburban boiler, where the essential loss in heating mains, installed another opportunity to improve the efficiency of heat supply systems. It is known that the amount of heat transferred to the object proportional to the temperature and volume of the heat transfer agent to the object (1), and this volume is determined by the electric drive of pumps.

$$
Q=V \rho(h \lambda-h \searrow),
$$

where $Q$ - amount of heat transferred to system; $V$ - volume of the heat transfer agent to the object; $h \nearrow, h \searrow-$ an enthalpy of the heat transfer agent departing in network and entering.

By increasing the coolant flow rate by $10 \%$ it is possible to reduce the temperature by $10 \%$ and thereby reduce the loss in heating duct (which increase with increasing flow temperature) and the boiler resource consumption.

Besides, as a rule, it is considered that the pump electric motor working directly from network or via of the Soft Start Device (SSD) doesn't maintained a constant rotation speed with a sufficient accuracy. At change of loading (volume of giving of the heat carrier) the speed of rotation of the electric motor of the pump can decrease by 5-10\%, reducing overall performance of a complex. Installation of the converter of frequency equipped with the special control algorithms providing the accuracy of maintenance of speed of rotation of the engine of the pump at changes in a hydraulic system at the level of $1 \%$ [3] can increase significantly system effectiveness in general.

Researches in system of heating of the suburban settlement are conducted. They have shown that installation of the converter of frequency with an algorithm of stabilization of speed of rotation on the network pump has allowed to stabilize a heat carrier expense, to increase it concerning an expense according to the standard scheme and to increase amount of the transferred heat without increase in temperature of the heat carrier. Increase in speed of rotation by $4-6 \%$ has allowed to increase amount of the transferred heat by $5-10 \%$ (Fig. 5).
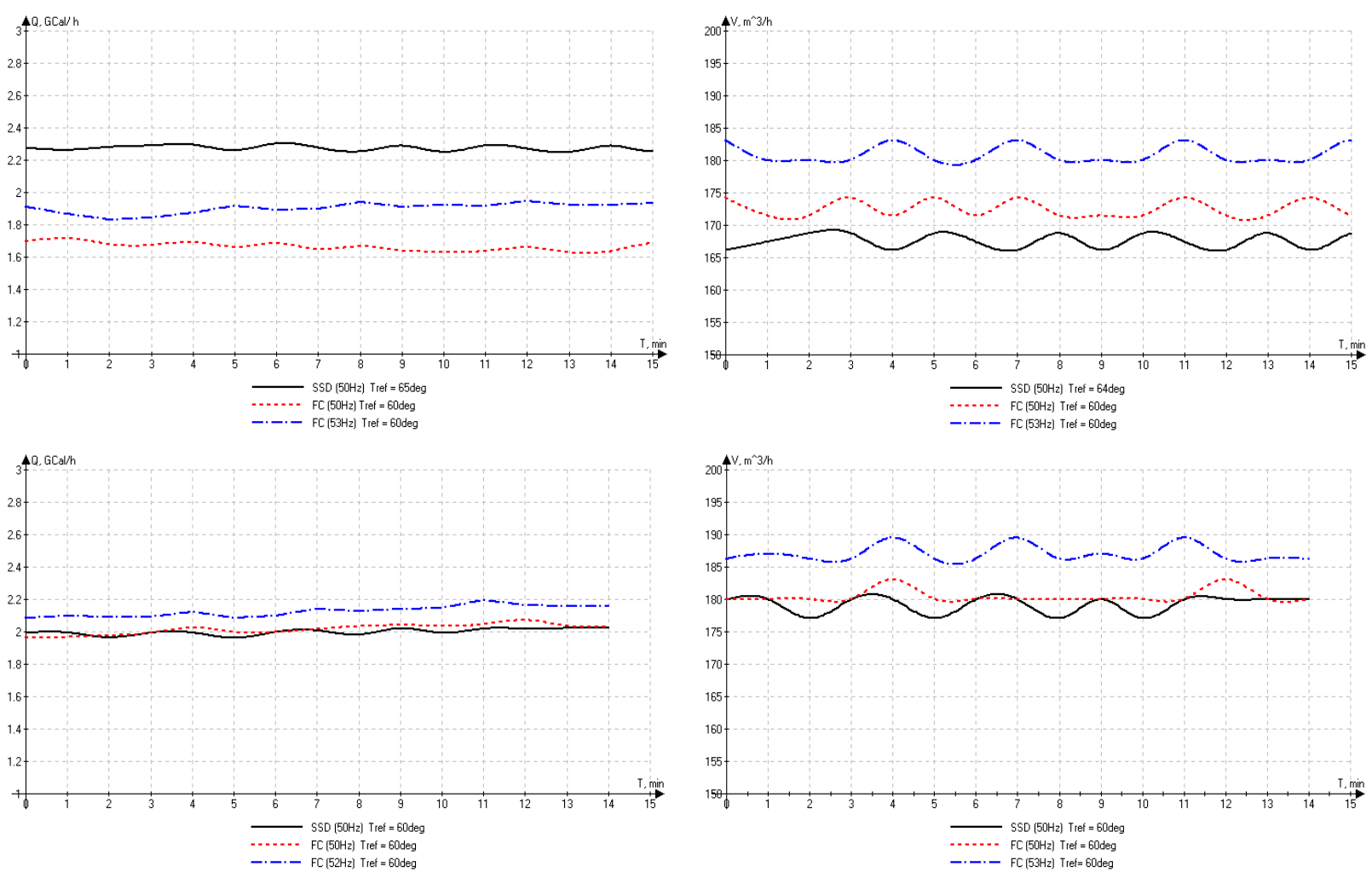

Fig. 5. The amount of heat transferred $(Q)$ and the coolant flow rate $(V)$ diagrams 


\title{
Conclusions
}

Trial operation of two various systems of heat supply has shown that improvement of quality of regulation of temperature of the heat carrier increases energy efficiency of these systems without serious material inputs. However, so far the organizations of technical supervision consider "excess" installation of converters of frequency on network pumps and demands an exception them from projects. Hopefully, in this article the results and further studies will convince these organizations in innovation efficiency.

\section{References}

1. Kachalin A.U., Kodkin V.L., Anikin A.S., Baldenkov A.A., Nemkov V.L. [Optimization of Energy Consumption in Heating Systems]. "Priorities of World Science. An Experiment and a Scientific Discussion": Materials XIII of the International Scientific and Practical Conference on June 17-18, 2015 Part 1. Natural and technical science. Northern Charleston, South Carolina, USA: CreateSpace, 2015, pp. 132-136. (in Russ.)

2. Vyalkova N.S. Sovershenstvovanie raboty kombinirovannoy sistemy vodyanogo i vozdushnogo otopleniya obshchestvennykh zdaniy: dis. kand. tekhn. nauk [Improving the Performance of the Combined System of Water and Air Heating of Public Buildings. Cand. Sci. Diss.]. Penza, PSU Pabl, 2011. $147 \mathrm{p}$.

3. Anikin A.S., Kodkin V.L., Baldenkov A.A. [Dynamic Positive Communication in Asynchronous Electric Drives with Frequency Control]. "Priorities of World Science. An Experiment and a Scientific Discussion": Materials XIII of the International Scientific and Practical Conference on June 17-18, 2015 Part 1. Natural and technical science. Northern Charleston, South Carolina, USA: CreateSpace, 2015. pp. 115-119. (in Russ.)

Received 7 February 2017

УдК 620.9:662.92; 658.264 + 658.012.01.56; 658.512

DOI: $10.14529 /$ ctcr170215

\section{ЭКСПЕРИМЕНТАЛЬНЫЕ ИССЛЕДОВАНИЯ ЭНЕРГОЭФФЕКТИВНОСТИ СИСТЕМ АВТОМАТИЧЕСКОГО УПРАВЛЕНИЯ ТЕПЛОСНАБЖЕНИЕМ ЖИЛЫХ ЗДАНИЙ И МЕТОДЫ ЕЕ ПОВЫШЕНИЯ}

\author{
В.Л. Кодкин, А.С. Аникин, А.А. Балденков, А.Ю. Качалин \\ Южно-Уральский государственный университет, г. Челябинск
}

\begin{abstract}
Приведены результаты опытной эксплуатации системы теплоснабжения жилого здания с оптимизированными процессами регулирования температуры теплоносителя. Проанализированы фактические показатели объемов потребленного газа за несколько месяцев 2015 года и значения температуры наружного воздуха в это же время. Показано, что заводские настройки регуляторов не обеспечивают эффективной работы, особенно при температурах наружного воздуха, близких к $0{ }^{\circ} \mathrm{C}$. Приведены данные, показавшие, что оптимизация процессов в системах отопления по разработанным методикам повышают их эффективность на10-15\%. На основе экспериментальных исследований в пригородной котельной со значительными потерями в теплотрассе, предложен метод повышения их энергоэффективности путем увеличения подачи теплоносителя. Метод реализован с помощью преобразователя частоты, установленного для управления сетевым насосом, и эксперименты подтвердили эффективность предложения.

Ключевые слова: оптимизация тепловых систем, энергоэффективность зданий, расход теплоносителя.
\end{abstract}




\section{Лumepamypa}

1. Оптимизация энергопотребления в тепловых системах / А.Ю. Качалин, В.Л. Кодкин, А.С. Аникин и др. // «Приоритеты мировой науки. Эксперимент и научная дискуссия»: материалы ХІІІ Междунар. науч.-практ. конф. 17-18 июня 2015 г-Часть 1. Естественные и технические науки. - Северный Чарльстон, Южная Каролина, США: CreateSpace, 2015. - C.132-136.

2. Вялкова, Н.С. Совершенствование работы комбинированной системы водяного и воздушного отопления общественных зданий: дис. ... канд. техн. наук / Н.С. Вялкова. - Пенза: Изд-во ПГУ, 2011. -147 c.

3. Аникин, А.С. Динамическая положительная связь в асинхронных электроприводах с частотным управлением / А.С. Аникин, В.Л. Кодкин, А.А. Балденков // материаль ХІІІ Междунар. науч.-практ. конф. 17-18 июня 2015 г - Часть 1. Естественные и технические науки. - Северный Чарльстон, Южная Каролина, США: CreateSpace, 2015. - C. 115-119.

Кодкин Владимир Львович, д-р техн. наук, профессор кафедры автоматизированного электропривода, Южно-Уральский государственный университет, г. Челябинск; kodkina2@mail.ru.

Аникин Александр Сергеевич, доцент кафедры теоретических основ электротехники, ЮжноУральский государственный университет, г. Челябинск; anikinsasha@gmail.ru.

Балденков Александр Александрович, аспирант кафедры автоматизированного электропривода, Южно-Уральский государственный университет, г. Челябинск; baloo@mail.ru.

Качалин Андрей Юрьевич, аспирант кафедры автоматизированного электропривода, Южно-Уральский государственный университет, г. Челябинск; kachalin89@inbox.ru.

Поступила в редакцию 7 ревраля 2017 г.

\section{ОБРАЗЕЦ ЦИТИРОВАНИЯ}

Experimental Studies of Energy Systems of Automatic Control Heat Supply of Residential Buildings and Methods of Increasing Their Efficiency / V.L. Kodkin, A.S. Anikin, A.A. Baldenkov, A.Yu. Kachalin // Вестник ЮУрГУ. Серия «Компьютерные технологии, управление, радиоэлектроника». - 2017. - Т. 17, № 2. C. 156-161. DOI: $10.14529 /$ ctcr170215

\section{FOR CITATION}

Kodkin V.L., Anikin A.S., Baldenkov A.A., Kachalin A.Yu. Experimental Studies of Energy Systems of Automatic Control Heat Supply of Residential Buildings and Methods of Increasing Their Efficiency. Bulletin of the South Ural State University. Ser. Computer Technologies, Automatic Control, Radio Electronics, 2017, vol. 17, no. 2, pp. 156-161. DOI: 10.14529/ctcr170215 